\title{
ANTI-OXIDANT AND ANTI-INFLAMMATORY POTENTIAL OF SECONDARY METABOLITES FROM Daphne mucronata ROYLE AND THEIR FIRST-PRINCIPLES INVESTIGATIONS
}

\author{
MUHAMMAD IMRAN ${ }^{1,2^{*}}$, AHMAD IRFAN ${ }^{1,2^{*}}$, SAJJAD HUSSAIN ${ }^{3}$, MOHAMMED A. ASSIRI $^{1}$, JALAL UDDIN $^{4}$, \\ AJAZ HUSSAIN ${ }^{5}$, NOREEN KHALID ${ }^{6}$ AND ABDULLAH G. AL-SEHEMI ${ }^{1,2}$
}

\author{
${ }^{1}$ Research Center for Advanced Materials Science, King Khalid University, P.O. Box 9004, Abha 61413, Saudi Arabia. \\ ${ }^{2}$ Department of Chemistry, College of Science, King Khalid University, P.O. Box 9004, Abha 61413, Saudi Arabia. \\ ${ }^{3}$ Department of Chemistry, University of Gujrat, Pakistan. \\ ${ }^{4}$ Department of Pharmaceutical Chemistry, College of Pharmacy, King Khalid University, P.O. Box 9004, Abha 62529, Saudi Arabia. \\ ${ }^{5}$ Institute of Chemical Sciences, Bahauddin Zakariya University, 60800, Multan, Pakistan. \\ ${ }^{6}$ Faculty of Pharmacy, University of Sargodha, Punjab, Pakistan.
}

\begin{abstract}
Ten coumarin class of compounds, including new fused coumarinolignoids namely, mucronin-C (1) were isolated from the methanol extract from whole plant of Daphne mucronata Royle. The structures of mucronin-C (1) and its configurations were determined by chemical and spectroscopic methods including 1DNMR, 2D-NMR and HR-FAB-MS. The isolated compounds 1-10 were evaluated for in-vitro biological activities. The anti-inflammatory (lipoxygenase) activities of compound 1, 4, 8, 9 and $10\left(\mathrm{IC}_{50}=21.7,23.7,25.1,27.3\right.$ and $26.0 \mu \mathrm{g} / \mathrm{mL}$, respectively) were higher compared with standard Quercetin $\left(\mathrm{IC}_{50}=22.5 \mu \mathrm{g} / \mathrm{mL}\right)$. The antioxidant property of coumarin as evaluated by DPPH scavenging bioassay was significantly greater in compounds 1-5, 9 and $\mathbf{1 0}\left(\mathrm{IC}_{50}=0.7,0.8,1.9,2.3,2.8,0.5\right.$ and $2.1 \mu \mathrm{g} / \mathrm{mL}$ respectively) as standard Trolox ( $\mathrm{IC}_{50}=0.3 \mu \mathrm{g} / \mathrm{mL}$ ). The density functional descriptors in the progress of quantitative structure-activity relationship (QSAR) are significant to analyze the reactive sites and antioxidant ability of compounds. We have explored the reactive sites and radical scavenging activity of studied coumarin derivatives by shedding light on electron affinity, ionization potential, molecular electrostatic potential, frontier molecular orbitals and molecular descriptors analysis. First-principles calculations about one-electron transfer mechanism revealed that smaller ionization potential value of Compounds 1-5, 9 and 10 are leading to superior antioxidant activity, which is in good agreement with the experimental data.
\end{abstract}

Keywords: Daphne mucronata Royle; mucronin-C; antioxidant activity; anti-inflammatory activity; density functional theory.

\section{INTRODUCTION}

The natural coumarinolignoids are the phenylpropanoid linked via 1,4 dioxne bridge with coumarin skeleton. These natural products are rare and show interesting biological activities including antioxidants, anti-inflammatory and hepatoprotective [1, 2]. Plant based natural products have been traditionally used to cure diseases. The herbal plant traditional medicines play vital role in primary health care across the world. The coumarin derivative are rich in genus Daphne (Thymlelaeaceae) plants. Coumarin possess anti-inflammatory potential also useful in treatment of oedema. They help in removal of proteins and oedemic fluids from injured tissue by enhancing phagocytosis, enzyme production which will leads to proteolysis [3]. Thymlelaeaceae family comprises of over 500 species and well-known 15 genera. The genus Daphne possesses well-known therapeutic properties. The reported phytochemicals constituents of this genus are coumarins, flavonoids [4], diterpenes, triterpenoids [5] lignans [6], and coumarinolignans [7]. The Daphne genus consisting of more than ninty five species distribiuted in Asia and Europe and it is considered as rare endangered plant in Sauida Arabia [8]. Some of its species are used in medicinal drugs and its bark used for the treatment of inflammation [9]. .Daphne mucronata Royle (D. mucronata) is used for the treatment of rheumatism, toothache, ulcer and muscular complications [10].

The inflammatory intermediates (leukotrienes: LTs, prostaglandins: PGs, and thromboxanes: TXs) responsible for inflammation as well as other physiological and pathological and methods. Enzymatic pathways produce these; lipoxygenase (LOX) and cyclooxygenase (COX) enzymes from a poly saturated fatty acid and arachidonic acid. The enzymes present in platelets (platelet aggregation), stomach (gastric protection), and kidneys (normal functions). Indomethacin and aspirin utilize their therapeutic potential via overwhelming PGs bio-synthesis through non-selective inhibition of COX enzymes resulting in serious adverse effects like bleeding, kidney, gastric and ulcer problems [11, 12]. It also leads to formation of mediators those leads to inflammatory as well as allergic processes including arthritis, psoriasis, dermatitis, chronic hives, Irritable bowel syndromes, asthmatic attack as well as rhinitis [13].

The disturbance of antioxidant in the body leads to oxidation stress resulted damage of nucleic acids, proteins, unsaturated fatty acids as well as polysaccharides.
The oxidation stress results in intense cell destruction which will leads to different type of human ailments such as Alzheimer, parkinsonism, cancerous processes, diabetes mellitus, atherosclerosis, damage of liver, arthritis, immunological compromise, degeneration of neurons as well as of inflammatory processes $[14,15]$. Antioxidants consumptions plays vital role in prevention of these diseases including stroke, cancer, inflammation and other degenerative processes [16] as well as to avoid undesirable changes in food. Previously oxidant inhibition activity of plant extract was analyzed where TLC (thin layer chromatography) strips were spread over the plates with $0.4 \%$ (w/v) 2, 2 diphenyl-1-picrylhydrazyl (DPPH) in methanol used as locating reagent [17]. The scavenging activity of free radicals is evidenced with yellow zones seeming on strips indicate its presence in extract of plant also indicate the presence of compounds those possess the oxidative potential [18].

The coumarin and its derivatives exhibit a variety of interesting biological activities. Therefore, they gained interest owing to their potential health benefits effects as well. Thus, it is important to shed light on various molecular descriptors, frontier molecular orbitals, ionization potential, electron affinity, and molecular electrostatic potential to understand the active sites and to explore the interesting biological activities especially the radical scavenging activity that has have been discussed in the current study. The global reactivity descriptors, e.g., electronegativity $(\chi)$, chemical potential $(\mu)$, chemical hardness $(\eta)$, electrophilicity index $(\omega)$ and softness $(\mathrm{S})$ were studied by density functional theory (DFT)

In this study we separate and purify new coumarinolignoids (1) along with known isolated phytochemicals mucronin-A (2) and mucronin-B (3), daphnecin (4), aquillochin (5), coumarin (6), 7-hydroxy coumarin (7), 7,8dihydroxyhydroxy coumarin (8) 6,7,8-trihydroxyhydroxy coumarin (9) and 6,7,8-trimethoxyhydroxy coumarin (10), from ethyl acetate soluble sub-fraction of D. mucronata (see Fig. 1). New compound structural elucidation was done with spectrometric and advanced spectroscopic techniques. The isolated pure phytochemicals were assessed for anti-inflammatory (lipoxygenase inhibitory potential) and antioxidants (DPPH scavenging bioassay) properties through invitro methods. 
<smiles>COc1ccc([C@@H]2Oc3cc4ccc(=O)oc4c(O)c3O[C@H]2CO)cc1OC</smiles><smiles>COc1cc([C@H]2Oc3cc4ccc(=O)oc4c(O)c3O[C@@H]2CO)cc(OC)c1O</smiles><smiles>COc1cc([C@H]2Oc3cc4ccc(=O)oc4c(OC)c3O[C@@H]2CO)cc(OC)c1O</smiles><smiles>COc1cc([C@@H]2Oc3c(c(O)cc4ccc(=O)oc34)O[C@H]2CO)cc(OC)c1O</smiles><smiles>COc1cc([C@@H]2Oc3c(c(OC)cc4ccc(=O)oc34)O[C@@H]2CO)cc(OC)c1O</smiles><smiles>O=c1ccc2ccccc2o1</smiles><smiles>O=c1ccc2cc(O)ccc2o1</smiles><smiles>O=c1ccc2c(O)c(O)ccc2o1</smiles><smiles>O=c1ccc2c(O)c(O)c(O)cc2o1</smiles><smiles>COc1cc2oc(=O)ccc2c(OC)c1OC</smiles>

Figure1. Structures of isolated compounds 1-10 from Daphne mисronate.

\section{EXPERIMENTAL}

\section{General experimental procedure}

Digital electronic balance with model (Model AUW 220D, Shimadzu, Japan), $\mathrm{pH}$ meter of (Inolab pH 720, Germany), Plate reader of (96-well), Sonicator (E3011 Elmasonic), 4-Incubator (Model MIR-153, Sanyo Electric Co., Ltd.). Shimadzu (460 Model) spectrometer for IR spectra, EI-MS and FAB-MS (+ive and -ive) were recorded on JMS-HX-110 and JMS-DA 5000 mass spectrometers. The ${ }^{1} \mathrm{H}$-NMR, ${ }^{13} \mathrm{C}$-NMR, and 2-D NMR spectra chemical shift values $(\delta)$ units and $J$ are in $\mathrm{Hz}$ were recorded on Bruker spectrometers operating at $300 \mathrm{MHz}$ $\left({ }^{1} \mathrm{H}-\mathrm{NMR}\right)$ and $100 \mathrm{MHz}\left({ }^{13} \mathrm{C}-\mathrm{NMR}\right)$, respectively. The. E-Merck aluminum sheets precoated with silica gel $60 \mathrm{~F}_{254}$ were used for TLC and E-Merck silica gel (230-400 mesh) was used for column chromatography. TLC plates visualization was done under UV (366 and 254nm) with Hitachi UV-3200 spectrometer followed by spraying with ceric sulfate reagent. All of chemicals were obtained from Sigma-Aldrich Co. St. Louis, Mo. USA.

\section{Plant material}

Daphne mucronata was collected from Pakistan (Gilgit) identified by University of Karachi, Plant Taxonomist, Prof. Suriya Khatoon, and where a voucher specimen (GP-0069-06) has been deposited.

\section{Extraction and isolation}

The whole plants of $D$. mucronata $(10 \mathrm{~kg})$ were dried, crushed and extracted with $\mathrm{CH}_{3} \mathrm{OH}$ at room temperature. The combined methanolic extract was evaporated in rotavapor under reduced pressure to obtain green blackish crude residue, dissolved in water and successively partitioned with $n$-hexane, dichloromethane (DCM), ethyl acetate (EtOAc) and $n$-butanol. The EtOAc soluble portion was subjected to $\mathrm{CC}$ on silica gel eluting hexane, dichloromethane (DCM) and $\mathrm{MeOH}$ to obtain five major fractions (A to E). The fraction A obtained by n-hexane-DCM (7.0:3.0) was further partitioned by CC with silica gel using $n$-hexane-DCM solvent mixture to attain further three major fractions. The Fraction $\mathrm{A}_{2}$ and $\mathrm{A}_{3}$ further purified by PTLC to give compounds 6 (n-hexane-DCM, 7.6:2.4 v/v), 7 (n-hexane-DCM, 6.2:3.8 v/v) and 10 $(\mathrm{n}$-hexane-DCM, 6.3:3.7 v/v). Other fraction B was eluted at n-hexane-DCM (5.0:5.0), on further purification by $\mathrm{CC}$ using silica gel as adsorbent gives two components mixture which on final purification gives compounds 8 (n-hexaneDCM, 5.3:4.7 v/v) and 9 (n-hexane-DCM, 4.9:5.1 v/v). The Fraction C attained by $\mathrm{n}$-hexane-DCM $(3.8: 6.2 \mathrm{v} / \mathrm{v})$ was finally purified by CC over silica gel eluting with n-hexane-DCM , gives mixture of three phytochemicals, which were finally isolated by CC using solvent system n-hexane-DCM (4.0:6.0), followed by PTLC to gives compounds 1 (n-hexane-DCM, 2.2:7.8 v/v), 3 (n-hexane-DCM, 2.5:7.5 v/v) and 5 (n-hexane-DCM, 2.0:8.0 v/v). The fraction D (n-hexane-DCM 2.0:8.0 v/v) was re-chromatographed over CC using silica gel and eluted with n-hexane-DCM (1.5:8.5) to afford 2 (n-hexane-DCM, 1.9:8.1 v/v) and 4 (n-hexane-DCM, 1.5:8.5 v/v) respectively.

Mucronin-C (1). Light yellow amorphous solid; $(20 \mathrm{mg}) \cdot[\alpha]_{\mathrm{D}}^{25}+52^{\circ}(c 0.35$, $\mathrm{MeOH}$ ); UV (MeOH) $\lambda_{\max } 341$ (4.01), 291 (3.18) and 238 (3.01) nm; IR (KBr) max: 1619, 1544 and 1436 (aromatic moieties), $1718(\mathrm{CO})$, and $3450 \mathrm{~cm}^{-1}(\mathrm{OH})$. ${ }^{1} \mathrm{H}-{ }^{13} \mathrm{C}-\mathrm{NMR}\left(\mathrm{C}_{5} \mathrm{D}_{5} \mathrm{~N}, 300\right.$ and $\left.100 \mathrm{MHz}\right)$ see Table 1; EI-MS $(\mathrm{m} / \mathrm{z})$ (rel. int.) 386 (26) [M] $]^{+}, 368$ (38), 353 (19), 325 (14), 210 (100), 178 (78), 167 (95), 150 (68), 121 (54), 82 (36), 77 (55) and 65 (59); FAB-MS (M-H m/z) 385: FAB-MS $(\mathrm{m} / \mathrm{z}) 387[\mathrm{M}+\mathrm{H}]^{+}$(calcd for $\mathrm{C}_{20} \mathrm{H}_{19} \mathrm{O}_{8}, 387.10275$ ). 
Table 1. NMR data of Mucronin-C (1) (300 MHz)- ${ }^{-1} \mathrm{H},(100 \mathrm{MHz})-{ }^{13} \mathrm{C}$.

\begin{tabular}{|c|c|c|c|}
\hline \multirow{2}{*}{ No. } & \multicolumn{3}{|c|}{1} \\
\hline & $\underline{\delta}_{C}$ & $\delta_{H}(J, \mathrm{~Hz})$ & HMBC \\
\hline 2 & 160.59 & - & - \\
\hline 3 & 113.84 & $6.37(1 \mathrm{H}, \mathrm{d}, J=9.5)$ & $2,4,9,10$ \\
\hline 4 & 144.56 & $7.68(1 \mathrm{H}, \mathrm{d}, J=9.5)$ & $2,3,5,9$ \\
\hline 5 & 106.35 & $7.56(1 \mathrm{H}, \mathrm{s})$ & $4,6,7,9$ \\
\hline 6 & 144.32 & - & - \\
\hline 7 & 138.58 & - & - \\
\hline 8 & 147.83 & - & - \\
\hline 9 & 149.39 & - & - \\
\hline 10 & 113.39 & - & - \\
\hline $1^{\prime}$ & 126.60 & - & - \\
\hline $2^{\prime}$ & 106.31 & $7.03(1 \mathrm{H}, \mathrm{d}, J=4.1)$ & $3^{\prime}, 1^{\prime}$ \\
\hline $3^{\prime}$ & 149.39 & - & - \\
\hline $4^{\prime}$ & 132.42 & - & - \\
\hline $5^{\prime}$ & 123.80 & $7.07(1 \mathrm{H}, \mathrm{d}, J=8.5)$ & $4^{\prime}, 6^{\prime} 2^{\prime}, 1^{\prime}$ \\
\hline $6^{\prime}$ & 113.86 & $7.01(1 \mathrm{H}, \mathrm{dd}, J=8.5,4.1)$ & $5^{\prime}, 1^{\prime}, 2^{\prime}$ \\
\hline $7^{\prime}$ & 80.11 & $5.58(1 \mathrm{H}, \mathrm{d}, J=8.14)$ & $9^{\prime}, 8^{\prime}, 6^{\prime}, 2^{\prime}$ \\
\hline $8^{\prime}$ & 77.97 & $4.45(1 \mathrm{H}, \mathrm{m})$ & $9^{\prime}, 7^{\prime}, 1^{\prime}$ \\
\hline $9^{\prime}$ & 60.82 & $\begin{array}{l}4.29(1 \mathrm{H}, \mathrm{d}, J=11.6) \\
3.91(1 \mathrm{H}, \mathrm{d}, J=11.6)\end{array}$ & - \\
\hline 3'-OMe & 56.45 & $3.87(3 \mathrm{H}, \mathrm{s})$ & $3^{\prime}$ \\
\hline 4'-OMe & 56.45 & $3.84(3 \mathrm{H}, \mathrm{s})$ & $4^{\prime}$ \\
\hline 8- $\mathrm{OH}$ & & 11.21 (bs) & - \\
\hline
\end{tabular}

\section{In-vitro anti-inflammatory assay}

The anti-inflammatory (lipoxygenase) activity was performed by standard method [19] with modifications. In this assay $200 \mu \mathrm{L}$ volume of lipoxygenase assay consisted of $150 \mu \mathrm{L}$ sodium phosphate buffer (100 mM with $\mathrm{pH} 8.0)$, test sample is $10 \mu \mathrm{L}$ as well as lipoxygenase enzyme in pure form is $15 \mu \mathrm{L}$. Pre read at $234 \mathrm{~nm}$ by mixing contents was performed also incubated for 10 minutes at room temperature. The addition of $25 \mu \mathrm{L}$ of substrate solution leads to reaction initiation. The absorbance change at $234 \mathrm{~nm}$ measured after $6 \mathrm{~min}$ and each assay performed in triplicate. Positive control Quercetin at $0.5 \mathrm{mM}_{\text {well }}{ }^{-1}$ concentration was used. The inhibition (\%) was found by formula below.

$\%$ Inhibition $=100-($ Abs. of test compound/Abs. of control $\times 100)$

\section{In-vitro antioxidant assay}

Antioxidant assay was measured by DPPH assay [20]. The principle of assay depends on that a hydrogen donator acts as antioxidant. In this assay radical accepts hydrogen from antioxidants. The oxidant inhibition effect was proportional to vanishing of DPPH radicals in test compounds and concentration $(0.5 \mu \mathrm{g} / \mathrm{ml})$ made in $\mathrm{CH}_{3} \mathrm{OH}$. Then $2.5 \mathrm{ml}$ solution of every compound concentration was add following the addition of $1 \mathrm{ml}$ of $0.3 \mathrm{mM}$ DPPH solution in methanol which is prepared freshly following the reaction in the dark at room temperature for half hour. At $518 \mathrm{~nm}$, absorbance of the whole solution measured. One mili litter of methanol was added in $2.5 \mathrm{ml}$ of every sample solution, which was using as a blank, while one mili litter of DPPH solution in concentration of $0.3 \mathrm{mM}$ was added to $2.5 \mathrm{ml}$ of methanol that was using as negative control. Trolox was made just like the test compound, which is using as a standard (positive controls) for differentiation. (\%) DPPH activities of the compounds as well as of standard determined as:

Inhibition $(\%)=100-($ Abs of compound $/$ Abs of control $) \times 100$.

$\mathrm{IC}_{50}$ values of compounds determined by the use of EZ-Fit Enzyme Kinetics Software (Perrella Scientific Inc. Amherst, USA).

\section{Computational details}

The density functional theory is an interesting tool to probe various properties of interests in biological sciences. DFT was systematically used to explore the electronic properties of functional materials, which positively reproduced the experimental data [21-23]. The DFT is consistent tool for the ground state $\left(\mathrm{S}_{0}\right)$ geometries and electronic properties, which was proved as a competent and trustworthy approach to efficiently optimize the $\mathrm{S}_{0}$ geometries of different compounds $[24,25]$. The B3LYP is rational for the $S_{0}$ geometries of various compounds [26]. Moreover, previous studies revealed that DFT is a rational approach to explore the antioxidant properties of various isolated compounds [27-29]. In present work, B3LYP/6-31G** level of theory was adopted to perform ground state geometries optimizations and electronic properties exploration in Gaussian16 software [30].

\section{RESULTS AND DISCUSSION}

The ethyl acetate soluble sub-fraction of the methanolic extract of the whole plant of Daphne mucronata was subjected to a series of column chromatographic techniques to obtain new coumarinolignans named as mucronin-C (1) four coumarinolignans $\mathbf{2 - 5}$ as well as five coumarin derivative compounds 6-10. The isolated compounds structures were elucidated by 1D-NMR, 2D-NMR, HRFAB-MS, UV and IR spectroscopy.

Mucronin-C (1) was purified as light yellow amorphous solid with molecular formula $\mathrm{C}_{20} \mathrm{H}_{19} \mathrm{O}_{8}$ as established with EIMS (386) as well as HR-FAB-MS showing $[\mathrm{M}+\mathrm{H}]^{+}$peak at $\mathrm{m} / z 387.1019$ (calcd for $\mathrm{C}_{20} \mathrm{H}_{19} \mathrm{O}_{8}, 387.10275$ ) and it was further supported with FAB-MS showing $[\mathrm{M}-\mathrm{H}]^{+}$peak at $\mathrm{m} / \mathrm{z}$ 385. The presence of aromatic moieties $\left(1619,1544\right.$ and $\left.1436 \mathrm{~cm}^{-1}\right)$, carbonyl group (1718 $\left.\mathrm{cm}^{-1}\right)$, and phenolic hydroxyl groups $\left(3450 \mathrm{~cm}^{-1}\right)$ functional group was confirmed by its IR absorptions bands. The UV spectrum of compound 1 showed coumarin skeleton absorption bands at 341 (4.01), 291 (3.18) and 238 (3.01) nm [7]. The ${ }^{1} \mathrm{H}-\mathrm{NMR}$ spectrum $\left(300 \mathrm{MHz}\right.$ pyridine- $\mathrm{d}_{5}$ ) revealed that compound $\mathbf{1}$ as a coumarin derivative. It showed a pair of $\mathrm{H}-4$ and $\mathrm{H}-3$ single proton doublets characteristic of coumarin moiety at $\delta 7.68(1 \mathrm{H}, \mathrm{d}, J=9.5 \mathrm{~Hz}, \mathrm{H}-4)$ and $\delta 6.37$ $(1 \mathrm{H}, \mathrm{d}, J=9.5 \mathrm{~Hz}, \mathrm{H}-3)$. Further signal resonated at $\delta 7.07(1 \mathrm{H}, \mathrm{d}, J=8.5 \mathrm{~Hz})$, $7.03(1 \mathrm{H}, \mathrm{d}, J=4.1 \mathrm{~Hz})$ and $\delta 7.01(1 \mathrm{H}, \mathrm{dd}, J=8.5,4.1 \mathrm{~Hz})$ indicated the tri substituted aromatic moiety within compound. The aromatic singlet was also observed at $\delta 7.56(1 \mathrm{H}, \mathrm{s})$ because of $\mathrm{H}-5$ and indicated 6,7-dioxygenated coumarin moiety $[31,32]$ along with hydroxyl group at C-8 resonated as $\delta 11.21$. The typical deshielded peak of benzylic oxygenated proton were observed at $\delta$ $5.58\left(1 \mathrm{H}, \mathrm{d}, J=8.14, \mathrm{H}-7^{\prime}\right)$, along with $\mathrm{H}-8^{\prime}$ signal at $\delta 4.45(1 \mathrm{H}, \mathrm{m})$ giving strong evidence the presence of phenylpropanoid $\delta 4.29,3.91\left(2 \mathrm{H}, \mathrm{d}, \mathrm{H}-9^{\prime}\right)$ and dioxane ring between coumarin corresponds to class of coumarinolignoid and its linkage was further verified with $2 \mathrm{D}-\mathrm{NMR}$ experiment. The ${ }^{13} \mathrm{C}-\mathrm{NMR}$ spectra broadband (BB) and distortionless enhancement by polarization transfer (DEPT) indicated the presence of twenty carbon signal comprising two methyl, one methylene, eight methine and nine quaternary carbons. The peaks at $\delta 80.11$ (C$\left.7^{\prime}\right), 77.97\left(\mathrm{C}-8^{\prime}\right)$ and $60.82\left(\mathrm{C}-9^{\prime}\right)$ give evidence the presence of phenylpropanoid unit in compound $\mathbf{1}$ and its further verification was done by 2D NMR spectra. The assignment of all peaks finally verified with 2-D NMR experiments. The long-range coupling $\mathrm{H}-5$ ( $\delta$ 7.56) to C-4, 6 and 9, were observed in HMBC experiments allowed assigning hydroxyl moiety at C-8.

The 1,4 dioxane ring trans diaxial arrangement at $\mathrm{H}-7$ and its position was confirmed by its large range coupling constant. These compounds usually isolated in racemates and showed no optical rotations. After chiral resolution, it showed electronic circular dichroism specific rotations $[\alpha]_{\mathrm{D}}^{25}+52$. The H-7' \& $\mathrm{H}-8^{\prime}$ coupling constant and its protons and carbons chemical shifts of at $\mathrm{H}-7^{\prime}$, H- $8^{\prime}$ give evidences $R$ and $S$ stereochemistry at C-7' and C-8' respectively [33]. Based on these evidences mucronin-C (1) was assigned the structure $(2 R, 3 S)$-2-(3,4-dimethoxyphenyl)-8-hydroxy-3-(hydroxymethyl)-2,3-dihydro- 
7H-[1,4]dioxino[2,3-g]chromen-7-one. All isolated constituents 1-10 evaluated for biological activities and showed promising results (Tables 2 and 3).

Table 2. Enzyme inhibition activities of compounds (1-10) against lipoxygenase.

\begin{tabular}{|c|c|c|}
\hline \multirow{2}{*}{ Compounds } & \multicolumn{2}{|c|}{ Lipoxygenase } \\
\cline { 2 - 3 } & Inhibition at conc. of $\mathbf{0 . 5} \boldsymbol{\mu \mathbf { g } / \mathbf { m L } ( \boldsymbol { \% } )}$ & $\mathbf{I C}_{\mathbf{5 0}}(\boldsymbol{\mu g} / \mathbf{m L})$ \\
\hline 1 & $93.4 \pm 0.03$ & $21.7 \pm 0.02$ \\
\hline 2 & $90.9 \pm 0.04$ & $35.5 \pm 0.03$ \\
\hline 3 & $68.2 \pm 0.01$ & $64.1 \pm 0.08$ \\
\hline 4 & $90.4 \pm 0.02$ & $23.7 \pm 0.05$ \\
\hline 5 & $70.4 \pm 0.05$ & $32.8 \pm 0.04$ \\
\hline 6 & $68.1 \pm 0.06$ & $105.7 \pm 0.05$ \\
\hline 7 & $83.4 \pm 0.01$ & $44.7 \pm 0.03$ \\
\hline 8 & $89.5 \pm 0.06$ & $25.1 \pm 0.09$ \\
\hline 9 & $95.2 \pm 0.05$ & $27.3 \pm 0.08$ \\
\hline 10 & $85.2 \pm 0.03$ & $26.1 \pm 0.05$ \\
\hline Quercetin & $93.8 \pm 0.08$ & $22.5 \pm 0.05$ \\
\hline
\end{tabular}

The compounds were analyzed in triplicate $(\mathrm{n}=3)$ and expressed as mean \pm standard deviation.

Table 3. Results of antioxidant activity of compounds (1-10) by DPPH method

\begin{tabular}{|c|c|c|}
\hline \multirow{2}{*}{ Compounds } & \multicolumn{2}{|c|}{ Antioxidant assay } \\
\cline { 2 - 3 } & Inhibition at conc. of $0.5 \mu \mathrm{g} / \mathrm{mL}(\%)$ & $\mathrm{IC}_{50}(\mu \mathrm{g} / \mathrm{mL})$ \\
\hline 1 & $93.5 \pm 0.06$ & $0.7 \pm 0.01$ \\
\hline 2 & $98.8 \pm 0.04$ & $0.8 \pm 0.06$ \\
\hline 3 & $89.9 \pm 0.02$ & $1.9 \pm 0.03$ \\
\hline 4 & $90.1 \pm 0.02$ & $2.3 \pm 0.07$ \\
\hline 5 & $85.2 \pm 0.09$ & $2.8 \pm 0.03$ \\
\hline 6 & $87.3 \pm 0.03$ & $26.7 \pm 0.07$ \\
\hline 7 & $85.2 \pm 0.05$ & $27.0 \pm 0.08$ \\
\hline 8 & $78.2 \pm 0.04$ & $32.1 \pm 0.05$ \\
\hline 9 & $96.4 \pm 0.05$ & $0.5 . \pm 0.06$ \\
\hline 10 & $55.1 \pm 0.07$ & $2.1 \pm 0.09$ \\
\hline Trolox & $96.3 \pm 0.01$ & $0.30 \pm 0.02$ \\
\hline
\end{tabular}

The compounds were analyzed in triplicate $(\mathrm{n}=3)$ and expressed as mean \pm standard deviation.

\section{In-vitro anti-inflammatory and anti-oxidant activity}

Both the anti-inflammatory as well as oxidant inhibition assays established an understanding for possible anti-inflammatory actions of drugs as inhibition of the lipoxygenases that is because of processes involves as inhibiting agents of free radicals produced at the active sites of enzymes [13]. Coumarins for antioxidant activity e.g. Fraxin at high concentration $(0.5 \mathrm{mM})$ showed free radical scavenging effect as well as cell protective corresponding to $\mathrm{H}_{2} \mathrm{O}_{2}$ generated oxidation stress. Esculetin is another example of coumarin possess antioxidant property [3]. Coumarin derivatives act as redox-active inhibitors against LOXs. Under the mentioned research, 6-subsituted coumarin derivatives were evaluated in vivo for inflammatory processes, analgesic actions, as well as of ulcerative risk [34]. As it can be seen in Table 2, the lipoxygenase activities of compound 1 was the strongest as its $\mathrm{IC}_{50}$ value 21.7 was highest at concentration $(0.5 \mu \mathrm{g} / \mathrm{mL})$ that is lower than standard Quercetin with $\mathrm{IC}_{50}=22.5$. The lipoxygenase activities of compounds 4, 8, 9 and $10\left(\mathrm{IC}_{50}=23.7,25.1,27.3\right.$ and $26.0 \mu \mathrm{g} / \mathrm{mL}$, respectively) showed the strongest. The compounds $\mathbf{2 , 5}$ and $\mathbf{7}$ exhibited intermediate lipoxygenase capacities, whereas compounds $\mathbf{3}$ and $\mathbf{6}$ showed the lowest lipoxygenase capacities $\left(\mathrm{IC}_{50}=105\right.$ and $\left.84 \mu \mathrm{g} / \mathrm{mL}\right)$.

As can be seen in Table 3, the DPPH scavenging activities of compound 1, 2, 9 was the strongest as its $\mathrm{IC}_{50}$ value was the lowest $(0.7,0.8$ and $0.5 \mu \mathrm{g} / \mathrm{mL}$ respectively) that is very close to standard Trolox $\left(\mathrm{IC}_{50}=0.30 \mu \mathrm{g} / \mathrm{mL}\right)$. The antioxidant activities of compounds $\mathbf{3 , 4 , 5}$ and $\mathbf{1 0}\left(\mathrm{IC}_{50}=1.9,2.3,2.8\right.$ and $2.1 \mu \mathrm{g} / \mathrm{mL}$, respectively) showed the significant activities. The compounds 6 and 7 exhibited intermediate antioxidant capacities in the range of 26.7 and 27.0 $\mu \mathrm{g} / \mathrm{mL}$, while $\mathbf{8}$ showed the lowest DPPH radical scavenging ability $\left(\mathrm{IC}_{50}=32.1\right.$ $\mu \mathrm{g} / \mathrm{mL})$.

\section{Why there is a Need of these inhibitors for future prospects}

Because of these side effects with existing NSAIDs, there is a need of novel agents with better therapeutic profile as anti-inflammatory drugs. Based on literature it has been found that coumarin and coumarin derivatives possess strongest anti-inflammatory as well as antioxidant activity. These studies strongly suggest that above discussed compounds can be used as potential candidate inhibitors so they can be used as future drugs against the said diseases discussed above e.g. alzheimer's disease, parkinson's disease, atherosclerosis, cancer, liver disease, diabetes, AIDS, arthritis, immunological incompetence, neurodegenerative disorders, inflammation, and so forth. Our study showed that compounds 1-5, 8 and 9 possess strongest antioxidant action and can be used potential candidate inhibitors and can be used as future drugs for prevention of oxidative stress. Our future work will be directly focused on toxicological as well as clinical trials of these coumarin compounds so they can be used in market with minimum side effects as compare to past drugs those are already used with major side effect like aspirn with ulceration side effect.

\section{Electronic properties}

The frontier molecular orbitals (FMOs), i.e., highest occupied molecular orbitals (HOMOs) and lowest unoccupied molecular orbitals (LUMOs) of coumarin compounds at B3LYP/6-31G** level are shown in Fig. 2. The intramolecular charge transfer (ICT) from HOMO $\rightarrow$ LUMO was observed. Reactive agents and free radicals also sternly correlate the antioxidant ability of compounds to the spatial distribution of HOMO revealing the most plausible sites in the studied compounds that can be certainly attacked. The energies of HOMO $\left(E_{\text {номо }}\right)$, LUMO $\left(E_{\text {LUMO }}\right)$, and HOMO-LUMO energy gaps $\left(E_{\text {gap }}\right)$ are important parameters to explore the electronic properties. The $E_{\text {HOMO }}, E_{L U M O}$, and $E_{\text {gap }}$ of coumarin compounds at $\mathrm{B} 3 \mathrm{LYP} / 6-31 \mathrm{G}^{* *}$ level at ground state $\left(\mathrm{S}_{0}\right)$ are displayed in Table 3 . The compounds with smaller $E_{\text {Номо }}$ values generally showed weaker electron donating aptitude revealed that Compounds 6-8 might have lesser electron donating capability compared to other counterparts. The $E_{\text {номо }}$ of Compounds 1-5, 9 and $\mathbf{1 0}$ is higher than the compounds 6-8, which exhibited those prior coumarins, would be better antioxidant contenders that is in good agreement with the experimental data. Global chemical reactivity descriptors (GCRD) are important parameters to realize the reactivity and structure stability. Here, we have calculated GCRD parameters like chemical hardness $(\eta)$, chemical potential $(\mu)$, electronegativity $(\chi)$, softness $(S)$ and electrophilicity index $(\omega)$ of coumarin compounds using HOMO and LUMO energy values, see Table 4 (for computational details see supporting information).

The $\eta$ of compound is interrelated to aromaticity $[35,36]$. The $\mu$ express the electron tendency to rush out from the electronic cloud. The $\eta$ also symbolizes extent of the obstruction of the electronic cloud to deformation and $\omega$ signifies the stabilization energy. The antioxidant compound deliver an electron to the free radical then caused radical cation should be stable enough for better radical scavenging ability in one-electron transfer mechanism. In this way the antioxidant ability can be evaluated by ionization potential (IP) than is a physical parameter enlightening the electron transfer range that can be estimated as $\mathrm{IP}=-E_{\text {Номо }}$. It is anticipated that radical scavenging nature might be superior for those compounds, which show smaller IP [27, 28].

Here, one can see from Table 4 that IP values of 1-5, 9 and $\mathbf{1 0}$ are smaller than rest of the coumarins which disclosed that prior compounds would show good antioxidant ability that is sound promising to measured radical scavenging ability which revealed that these compounds might also be good anti-COVID-19 contenders as better antioxidant compounds would lead to better antiviral ability. 

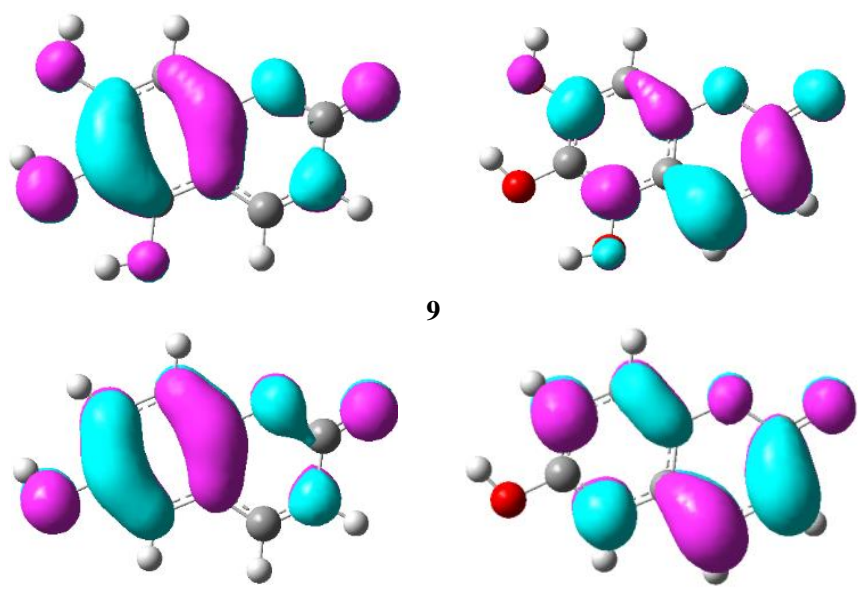

7

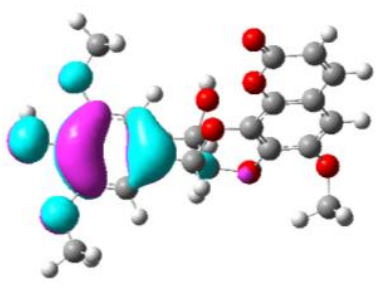

5
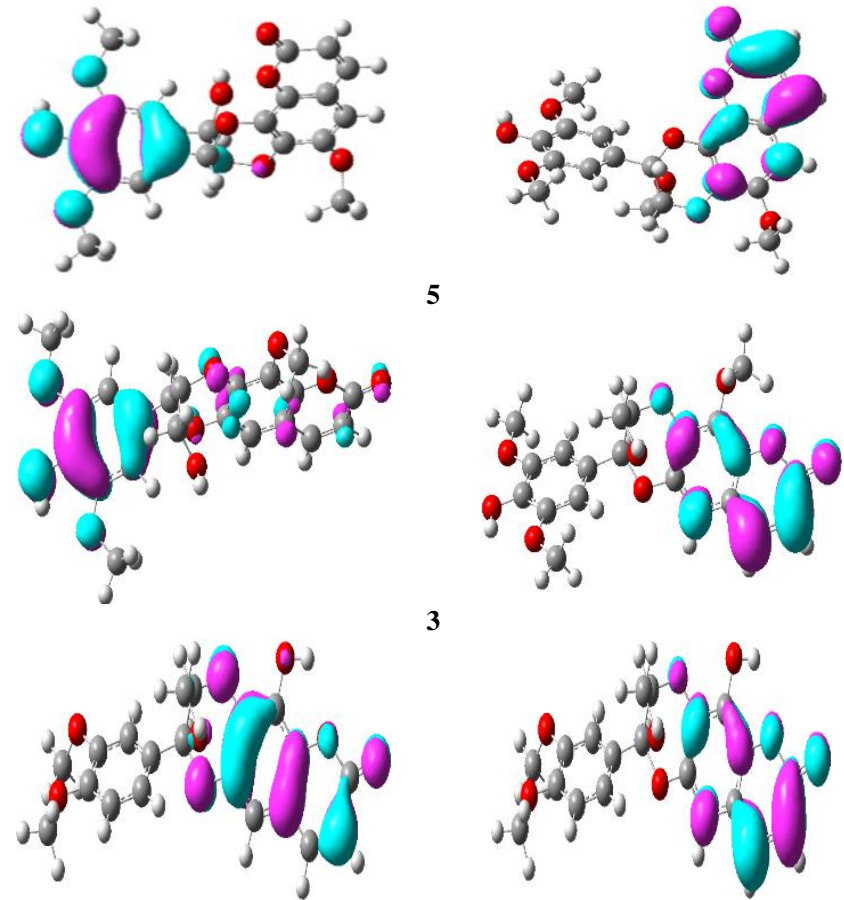

HOMO
3

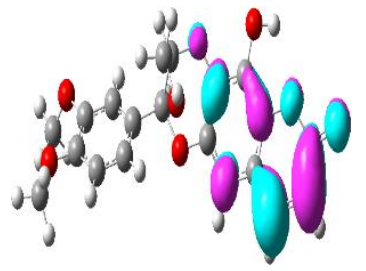

LUMO

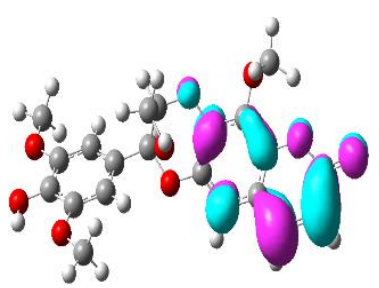

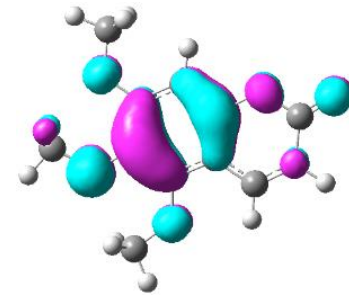

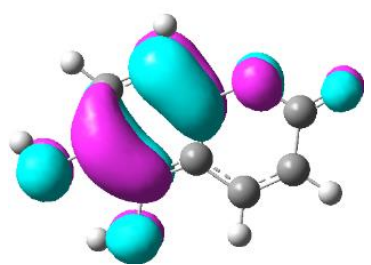

10
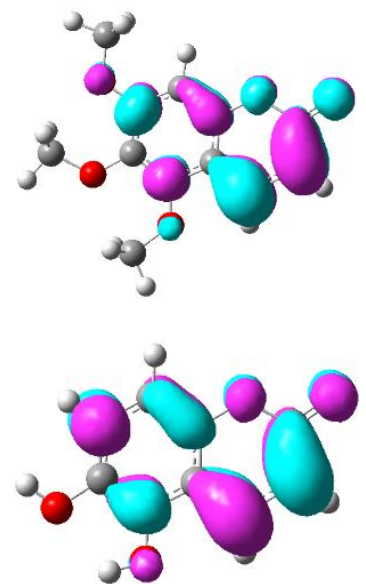

8
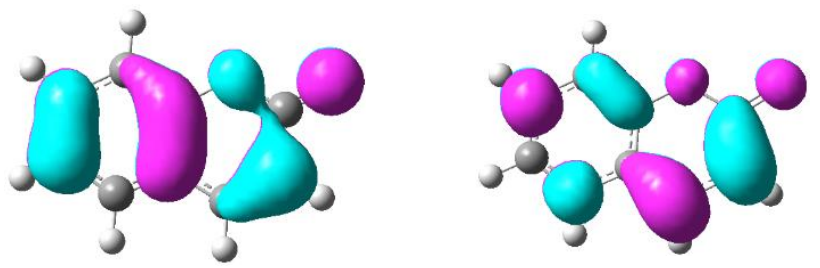

6
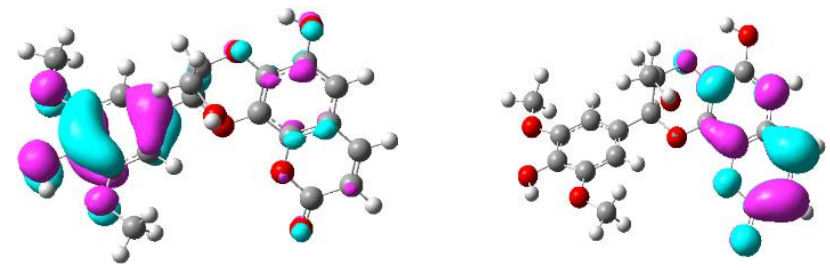

4

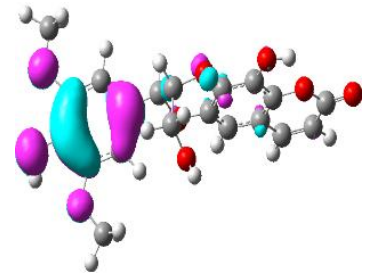

HOMO

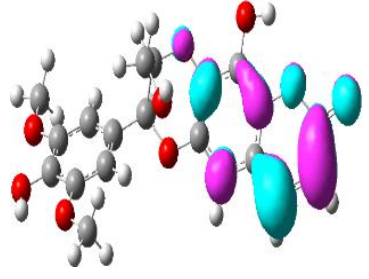

LUMO

Figure 2. Ground state charge density of frontier molecular orbitals (HOMOs) and (LUMOs) of compounds (1-10) (contour value $=0.035)$.

The Molecular electrostatic potential (MEP) maps are important to visualize the charged region of compounds. In Fig. 3, the MEP mapped for coumarin compounds has been illustrated in color visualizations. The red and blue color identifies the sophisticated negative and positive potential regions, which would be favorable for electrophilic and nucleophilic attack, respectively. The concentrated negative electrostatic potential is distributed on the oxygen atoms of $-\mathrm{OH}$ and $-\mathrm{OCH}_{3}$ while positive potential is determined on hydrogen atoms of
$-\mathrm{OH}$ and $-\mathrm{OCH}_{3}$. The MEP mapped revealed that red color concentrated sites (oxygen) would be more feasible site for electrophilic attack. The blue color on hydrogen atom of $-\mathrm{OH}$ exposed that these sites would be favorable for nucleophilic attack. The favorable active sites can be found on the Compounds 1-5, 9 and 10 which is illuminating that these coumarins would be better antioxidant candidates which is in good agreement with experimental evidences.

Table 4. The ground state HOMO energies ( $\left.E_{\text {номо }}\right)$, LUMO energies $\left(E_{L U M O}\right)$, energy gaps $\left(\triangle E_{\text {номо-LUMO }}\right)$, IP, EA, $\eta, \mu, S, \chi$ and $\omega$ in eV of compounds $(\mathbf{1 - 1 0})$.

\begin{tabular}{|l|c|c|c|c|c|c|c|c|c|c|}
\hline Parameters & $\mathbf{1}$ & $\mathbf{2}$ & $\mathbf{3}$ & $\mathbf{4}$ & $\mathbf{5}$ & $\mathbf{6}$ & $\mathbf{7}$ & $\mathbf{8}$ & $\mathbf{9}$ & $\mathbf{1 0}$ \\
\hline$E_{\text {HOMO }}$ & -5.60 & -5.52 & -5.54 & -5.48 & -5.43 & -6.50 & -6.08 & -5.97 & -5.86 & -5.49 \\
\hline$E_{\text {LUMO }}$ & -1.53 & -1.58 & -1.49 & -1.42 & -1.44 & -1.89 & -1.89 & -1.72 & -1.55 & -1.38 \\
\hline$E_{\text {gap }}$ & 4.07 & 3.94 & 4.05 & 4.06 & 3.99 & 4.61 & 4.19 & 4.25 & 4.31 & 4.11 \\
\hline Hardness $(\eta)$ & 2.035 & 1.970 & 2.025 & 2.030 & 1.995 & 2.305 & 2.095 & 2.125 & 2.155 & 2.055 \\
\hline Potential $(\mu)$ & -3.565 & -3.550 & -3.515 & -3.450 & -3.435 & -4.195 & -3.985 & -3.845 & -3.705 & -3.435 \\
\hline Softness $(S)$ & 1.376 & 1.401 & 1.368 & 1.350 & 1.361 & 1.410 & 1.451 & 1.404 & 1.360 & 1.336 \\
\hline Electronegativity $(\chi)$ & 3.565 & 3.550 & 3.515 & 3.450 & 3.435 & 4.195 & 3.985 & 3.845 & 3.705 & 3.435 \\
\hline Electrophilic index $(\omega)$ & 3.123 & 3.199 & 3.051 & 2.932 & 2.957 & 3.817 & 3.790 & 3.478 & 3.185 & 2.871 \\
\hline Ionization potential (IP) & 5.60 & 5.52 & 5.54 & 5.48 & 5.43 & 6.50 & 6.08 & 5.97 & 5.86 & 5.49 \\
\hline Electron affinity (EA) & 1.53 & 1.58 & 1.49 & 1.42 & 1.44 & 1.89 & 1.89 & 1.72 & 1.55 & 1.38 \\
\hline
\end{tabular}




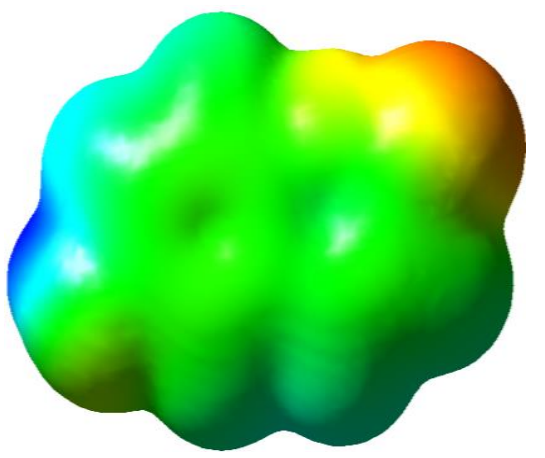

7

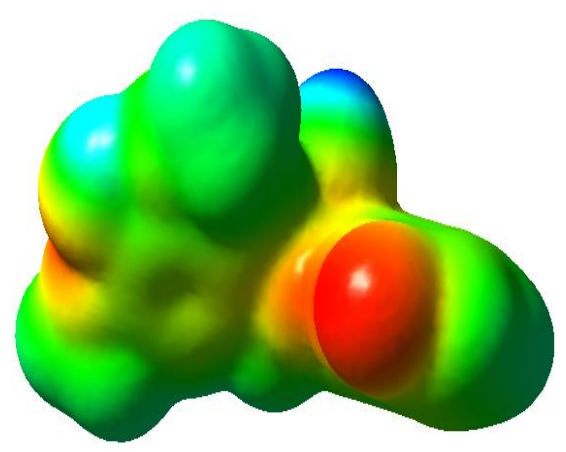

4

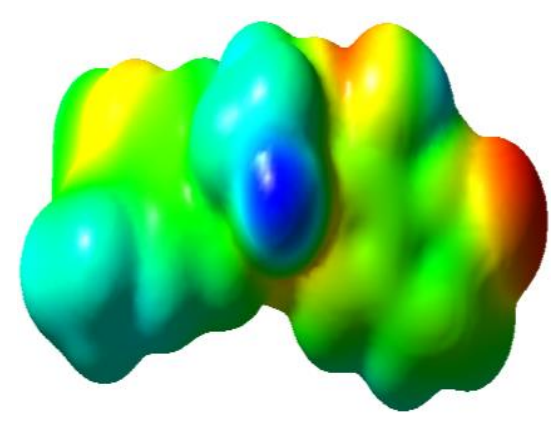

1

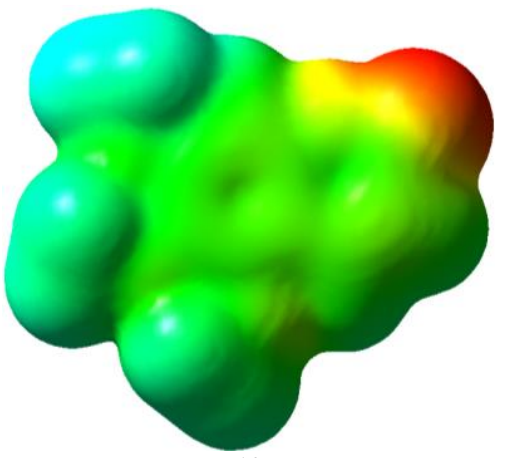

10

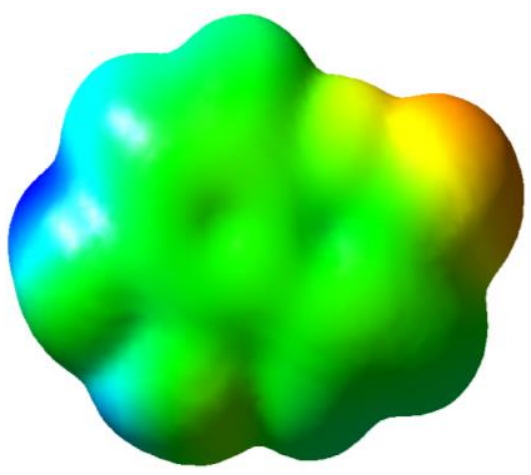

8

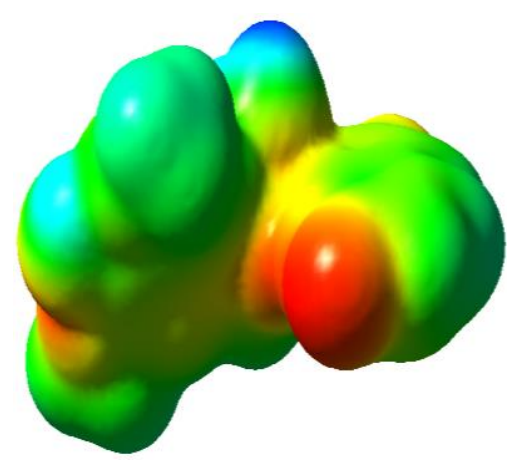

5

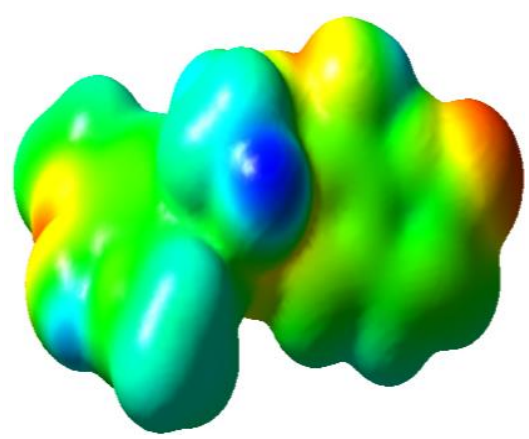

2

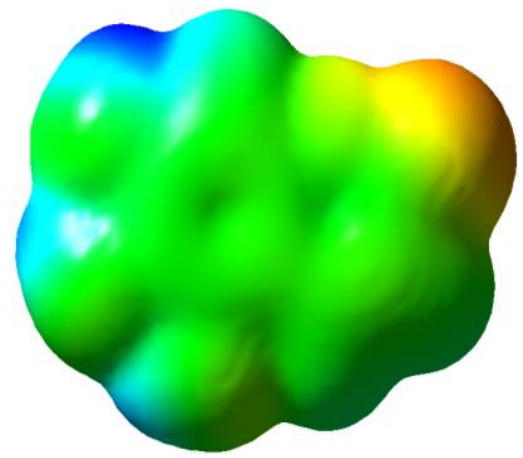

9

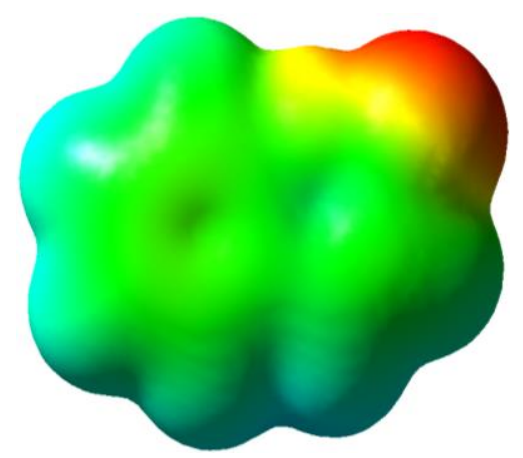

6

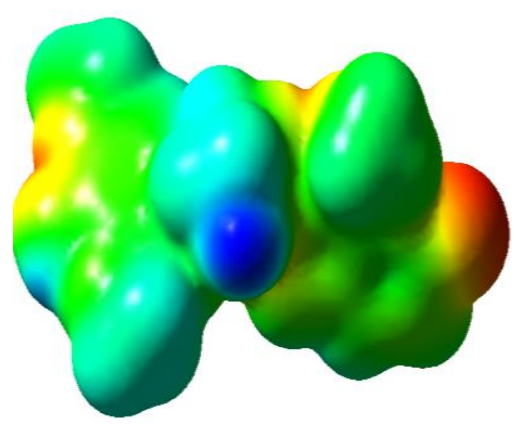

3

Figure 3. Molecular electrostatic potential surfaces views of compounds (1-10).

\section{CONCLUSIONS}

The medicinal use of Daphne species as anti-inflammatory and antioxidants has prompted to isolate biologically active constituents from Daphne mucronata Royle. We have investigated isolation and structural characterization of new fused coumarinolignoids namely, mucronin-C (1) as well as four coumarinolignans (2-5), five coumarin derivative (6-10) from EtOAc solule portions. In-vitro anti-inflammatory (lipoxygenase activities) and antioxidants (DPPH scavenging bioassay) showed promising results. These compounds from D. mucronata exhibited their potential bioactivities as anti-inflammatory and antioxidants phytochemicals. The intra-molecular charge transfer was observed from $\mathrm{HOMO} \rightarrow$ LUMO. The compounds with higher HOMO energies displayed strong electron donating ability, which revealed that 1-5, 9 and 10 coumarin compounds might have superior electron donating capability that exhibited that these compounds would be better antioxidant contenders. The electrophilic and nucleophilic favorable active sites and smaller IP values of 1-5, 9 and $\mathbf{1 0}$ disclosed that these compounds would show good antioxidant ability that is sound promising to measured radical scavenging ability in present study. These can be used as potential candidate inhibitors so can be used as future drugs against the diseases discussed above. 


\section{ACKNOWLEDGEMENTS}

We extend appreciation to the Deanship of Scientific Research at King Khalid University (KKU), Saudi Arabia for funding through research groups program under grant number R.G.P.2/24/42.

\section{CONFLICT OF INTEREST}

No potential conflict of interest was reported by authors.

\section{REFERENCES}

1. S. Oran, D. Al-Eisawi, Check-list of medicinal plants in Jordan. Dirasat 25(2) 84-112 (1998).

2. J.-J. Chen, T.-Y. Wang, T.-L. Hwang, Neolignans, a coumarinolignan, lignan derivatives, and a chromene: anti-inflammatory constituents from Zanthoxylum avicennae. Journal of natural products 71(2) 212-217 (2008).

3. K. N. Venugopala, V. Rashmi , B. Odhav, Review on natural coumarin lead compounds for their pharmacological activity. BioMed research international 2013 (2013).

4. M. A. Rasool, M. Imran, H. Nawaz, A. Malik, S. U. Kazmi, Phytochemical studies on Daphne mucronata. Journal-Chemical Society of Pakistan 31(5) 845-850 (2009).

5. Z. Khodadadian, M. Hassanpour-Ezatti, S. Z. Mousavi , J. Asgarpanah, Analgesic and anti-inflammatory potential of aerial parts of the Daphne mucronata Royle extract in mice: Opioid-independent action. Asian Pacific Journal of Tropical Biomedicine 6(3) 198-201 (2016).

6. N. Ullah, S. Ahmed, P. Muhammad, Z. Ahmed, H. R. Nawaz, A. Malik, Coumarinolignoid glycoside from Daphne oleoides. Phytochemistry 51(1) 103-105 (1999).

7. S. Ferheen, M. A. Rasool, B. Naqvi, M. Imran, R. A. Khan, M. A. Kalhoro, A. Malik, Anti-tuberculosis coumarinolignans from Daphne mucronata. Asian Journal of Chemistry 26(21) 7262 (2014).

8. S. Collenette, Wildflowers of Saudi Arabia1999: National Commission for Wildlife Conservation and Development (NCWCD).

9. M. Ballero, F. Poli, G. Sacchetti , M. C. Loi, Ethnobotanical research in the territory of Fluminimaggiore (south-western Sardinia). Fitoterapia 72(7) 788801 (2001).

10. W. Murad, A. Ahmad, S. A. Gilani, M. A. Khan, Indigenous knowledge and folk use of medicinal plants by the tribal communities of Hazar Nao Forest, Malakand District, North Pakistan. Journal of Medicinal Plants Research 5(7) 1072-1086 (2011).

11. M. A. Abdelgawad, M. B. Labib, W. A. Ali, G. Kamel, A. A. Azouz, E.-N. EL-Shaymaa, Design, synthesis, analgesic, anti-inflammatory activity of novel pyrazolones possessing aminosulfonyl pharmacophore as inhibitors of COX-2/5-LOX enzymes: Histopathological and docking studies. Bioorganic chemistry 78 103-114 (2018).

12. H. G. Choi, P. T. Tran, J.-H. Lee, B. S. Min , J. A. Kim, Anti-inflammatory activity of caffeic acid derivatives isolated from the roots of Salvia miltiorrhiza Bunge. Archives of pharmacal research 41(1) 64-70 (2018).

13. R. Mogana, K. Teng-Jin , C. Wiart, Anti-inflammatory, anticholinesterase, and antioxidant potential of scopoletin isolated from Canarium patentinervium Miq.(Burseraceae Kunth). Evidence-based complementary and alternative medicine 2013 (2013).

14. M. Allegra, Antioxidant and Anti-Inflammatory Properties of Plants Extract, 2019, Multidisciplinary Digital Publishing Institute

15. Y. J. Lee, W. I. Kim, S. Y. Kim, S. W. Cho, H. S. Nam, S. H. Lee, M. K. Cho, Flavonoid morin inhibits proliferation and induces apoptosis of melanoma cells by regulating reactive oxygen species, Sp1 and Mcl-1. Archives of pharmacal research 42(6) 531-542 (2019).

16. E. Zielińska, B. Baraniak , M. Karaś, Identification of antioxidant and antiinflammatory peptides obtained by simulated gastrointestinal digestion of three edible insects species (Gryllodes sigillatus, Tenebrio molitor, Schistocerca gragaria). International journal of food science \& technology 53(11) 2542-2551 (2018).

17.E. Ahmed, M. Imran, A. Malik , M. Ashraf, Antioxidant activity with flavonoidal constituents fromAerva persica. Archives of pharmacal research 29(5) 343-347 (2006).

18. C. Deby , G. Magotteaux, Relationship between essential fatty acids and tissue antioxidant levels in mice. Comptes Rendus des Seances de la Societe de Biologie et de ses Filiales 164(12) 2675-2681 (1970).

19. S. Baylac, P. Racine, Inhibition of 5-lipoxygenase by essential oils and other natural fragrant extracts. International Journal of Aromatherapy 13(2-3) 138142 (2003).

20. L. L. Mensor, F. S. Menezes, G. G. Leitão, A. S. Reis, T. C. d. Santos, C. S Coube, S. G. Leitão, Screening of Brazilian plant extracts for antioxidant activity by the use of DPPH free radical method. Phytotherapy research 15(2) 127-130 (2001)

21. M. Najafi, S. A. R. Naqvi, Theoretical study of the substituent effect on the hydrogen atom transfer mechanism of the irigenin derivatives antioxidant action. Journal of Theoretical and Computational Chemistry 13(02) 1450010 (2014).

22. D. Mikulski, K. Eder , M. Molski, Quantum-chemical study on relationship between structure and antioxidant properties of hepatoprotective compounds occurring in Cynara scolymus and Silybum marianum. Journal of Theoretical and Computational Chemistry 13(01) 1450004 (2014).

23. K. SADASIVAM, R. JAYAPRAKASAM , R. KUMARESAN, A DFT STUDY ON THE ROLE OF DIFFERENT OH GROUPS IN THE RADICAL SCAVENGING PROCESS. Journal of Theoretical and Computational Chemistry 11(04) 871-893 (2012).

24. Mahmood, A. Irfan, First principles investigations of geometric, electronic and optical properties of 5 -aminotetrazole derivatives. Journal of Computational Electronics 12(3) 437-447 (2013).

25. A. Irfan, M. Assiri , A. G. Al-Sehemi, Exploring the optoelectronic and charge transfer performance of diaza[5] helicenes at molecular and bulk level. Organic Electronics 57 211-220 (2018).

26. J. Preat, D. Jacquemin , E. A. Perpète, Design of New TriphenylamineSensitized Solar Cells: A Theoretical Approach. Environmental Science \& Technology 44(14) 5666-5671 (2010).

27. A. G. Al-Sehemi , A. Irfan, Effect of donor and acceptor groups on radical scavenging activity of phenol by density functional theory. Arabian Journal of Chemistry 10(Supplement 2) S1703-S1710 (2017).

28. A. G. Al-Sehemi, A. Irfan, S. M. Aljubiri , K. H. Shaker, Density functional theory investigations of radical scavenging activity of $3^{\prime}$-Methyl-quercetin. Journal of Saudi Chemical Society 20, Supplement 1 S21-S28 (2016).

29. A. G. Al-Sehemi, A. Irfan, S. M. Aljubiri , K. H. Shaker, COMBINED EXPERIMENTAL AND COMPUTATIONAL STUDY OF THE RADICAL SCAVENGING ACTIVITY OF LUTEOLIN. Journal of Theoretical and Computational Chemistry 12(05) 1350021 (2013).

30. Frisch MJ, Trucks GW, Schlegel HB et al.,, Gaussian-16, Revision A.1, Gaussian, Inc., Wallingford, CT, 2016.

31. B. Sajeli, M. Sahai, R. Suessmuth, T. Asai, N. Hara, Y. Fujimoto, Hyosgerin, a new optically active coumarinolignan, from the seeds of Hyoscyamus niger. Chemical and pharmaceutical bulletin 54(4) 538-541 (2006).

32. A. Magalhães, M. D. G. Zoghbi , A. C. Siani, 5-Methoxypropacin, a novel coumarinolignoid from Protium unifoliolatum. Natural product research 20(1) 43-46 (2006)

33. C. Ma, H. J. Zhang, G. T. Tan, N. V. Hung, N. M. Cuong, D. D. Soejarto , H H. Fong, Antimalarial compounds from Grewia bilamellata. Journal of natural products 69(3) 346-350 (2006)

34. P. Srivastava, V. K. Vyas, B. Variya, P. Patel, G. Qureshi, M. Ghate, Synthesis, anti-inflammatory, analgesic, 5-lipoxygenase (5-LOX) inhibition activities, and molecular docking study of 7-substituted coumarin derivatives. Bioorganic chemistry 67 130-138 (2016).

35. A. Vektariene, G. Vektaris, J. Svoboda, A theoretical approach to the nucleophilic behavior of benzofused thieno [3, 2-b] furans using DFT and HF based reactivity descriptors. Arkivoc $7311-329$ (2009).

36. P. Geerlings, F. De Proft, W. Langenaeker, Conceptual density functional theory. Chemical Reviews 103(5) 1793-1874 (2003). 